\title{
Ksztaltowanie się firm informatycznych jako nowych elementów struktury przestrzennej przemysłu
}

Postępujący proces rozwoju społeczno-gospodarczego związany z przechodzeniem $\mathrm{z}$ fazy postindustrialnej do fazy informacyjnej przejawia się w powstawaniu nowych sektorów gospodarczych oraz instytucji, które podejmują nowe funkcje wynikających z nowych potrzeb postępu cywilizacyjnego. Istotną cecha społeczeństwa informacyjnego jest pojawianie się firm, które reprezentują nowy sektor przedsiębiorstw związanych z IT. Zróżnicowana przestrzeń geograficzna, przejawiająca się w określonym poziomie rozwoju społeczno-gospodarczego różnej skali układów przestrzennych (od skali globalnej po skalę lokalną) sprawia, że układy te stwarzają często odmienne uwarunkowania dla nowych impulsów rozwojowych związanych z fazą rozwoju informacyjnego na ich obszarze (Kukliński 2001, Wierzbicki 1995, Zioło 2001, 2003).

W świetle przedstawionych przesłanek w niniejszych rozważaniach podjęto problematykę kształtowania się firm informatycznych w przestrzeni krajowej jako nowych elementów struktury przestrzennej przemysłu. Zmierzać będziemy do określenie tempa pojawiania się firm informatycznych oraz ich wpływu na różnicowanie przestrzeni krajowej. W procesie kształtowania się firm informatycznych na terenie naszego kraju zaznaczają się dwie tendencje, jedna to podejmowanie działalności informatycznej przez firmy prowadzące wcześniej inną działalność, druga zaś to firmy, które od początku związane były z działalnością informatyczną.

$\mathrm{Na}$ wstępnie przyjmujemy tezę, że pojawianie się firm informatycznych na terenie różnej skali układów przestrzennych jest wyrazem wkracza ich w fazę informacyjnego rozwoju. Zmienianie profilu działalności istniejących wcześniej firmy na informatyczną czy powstawanie nowych firm związanych $\mathrm{z}$ informatyką wynika bowiem z nowych potrzeb rynkowych pojawiających się w różnorodnych przedsiębiorstwach produkcyjnych, usługowych, czy instytucjach. Związane są one z dążeniem do podnoszenia konkurencyjności swojej działalności, co powoduje konieczność zmian organizacji pracy oraz przekazywania lub przyjmowania określonych informacji niezbędnych dla sprawniejszego czy efektywniejszego działania.

Ważnym zagadnieniem w tym zakresie jest określenie potencjału, rozmiarów i stopnia nasilenia działalności informatycznej w różnej skali układach przestrzennych. Istotny jest tu wybór odpowiednich mierników, które odnoszą się do różnych aspektów działalności firm informatycznych, a to: 
- wielkości potencjału firm informatycznych, który określa: liczba firm informatycznych, potencjalne możliwości ich pracy, wartość majątku, wartość rynkowa czy wartość akcji,

- rozmiarów działalności firm: wartość przychodów, przychody na 1 pracującego,

- efektywności działalności firm: wielkość zysków, zysk na 1 pracującego,

- możliwości rozwoju: wartość nakładów inwestycyjnych,

- rynku pracy: liczba pracujących, liczba pracujących na umowy (zlecenia) czy liczba zatrudnionych,

- nasilenia działalności firm informatycznych, które określają wskaźniki przyjmujące jako układ odniesienia: powierzchnię danej jednostki przestrzennej (np. liczba firm na $100 \mathrm{~km}^{2}$, wartość przychodów na $100 \mathrm{~km}^{2}$ ), ludności (np. przychody na 1000 mieszkańców), liczbę pracujących (np. liczba pracujących w firmach informatycznych do liczby pracujących ogółem), wartości PKB i in.

Firmy informatyczne na terenie naszego kraju pojawiły się stosunkowo niedawno i należy je traktować jako nowe elementy struktury przestrzennej przemysłu. Proces kształtowania się firm informatycznych był bardzo zróżnicowany i nawiązywał do tempa wkraczania informatyzacji do życia społeczno-gospodarczego. Analizując 700 największych krajowych firm informatycznych funkcjonujących w 2002 r., okazuje się, że powstawały one lub podejmowały działalność informatyczną w zasadzie po 1986 r. (tab. 1). Do 1986 r. tylko

6 firm reprezentowało działalność informatyczną. Były to głównie ośrodki obliczeniowe ETO zlokalizowane najwcześniej w wiodących miastach w 1965 r. (Warszawa, Katowice, Kraków, Łódź, Poznań) i w 1966 r. (Bydgoszcz, Gdynia, Rzeszów).

W następnych latach proces kształtowania się firm informatycznych był bardzo zróżnicowany, czego wyrazem jest wahająca się liczba firm podejmujących działalność informatyczną od 6 w 1986 r. do 71 w 2000. Najbardziej dynamiczny rozwój przedsiębiorstw informatycznych nastąpił w latach 1987-2000, kiedy ich liczba stopniowo zwiększała się z 19 do 71. Najwięcej ze współcześnie działających firm informatycznych powstało w latach 1995-2001, z którego to okresu pochodzi 389 przedmiotów, tj. 55,6\% firm obecnie funkcjonujących. Firmy informatyczne charakteryzują się bardzo zróżnicowanym potencjałem ekonomicznym. Wskazuje na to zróżnicowana wartość dochodów, która waha się od 1,4 mln zł dla firm powstałych w $1985 \mathrm{r}$. do 2,6 mld zł dla firm powstałych w $1997 \mathrm{r}$.

W obecnym potencjale gospodarczym firm informatycznych największe znaczenie odgrywają firmy powstałe w latach 1991-2001, które miały znacznie więcej czasu na rozwój i zdobycie doświadczenia w zakresie funkcjonowania oraz pierwsze opanowały rynek. Reprezentuje je 485 firm, które stanowią 69,3\% ogólnej ich liczby, a łączne przychody tych przedsiębiorstw obejmują 78,7\% ogólnych przychodów krajowych firm informatycznych. Znacznie mniejszą rolę odgrywają firmy powstałe do $1990 \mathrm{r}$. Reprezentuje je 98 firm, tj. 14,0\% ich ogólnej liczby, a ich łączne przychody wynoszą 16,0\% ogólnych przychodów. Podobnie znacznie mniejsze znaczenia mają firmy powstałe po 2001 r., które stanowią $7,1 \%$ ogólnej liczby firm, a obejmują tylko 1,8\% ogólnych przychodów. Pod względem przychodów dominujące znaczenie mają firmy powstałe w latach 1991 i 1996-1997. Reprezentuje je 140 jednostek, czyli 20,0\% i obejmują 31,8\% ogólnych przychodów.

Współcześnie funkcjonujące firmy, jak już wspomniano, podejmowały działalność informatyczną od początku swojego powstania lub zmieniały wcześniejszy profil działalności na informatyczny. W konsekwencji występują pewne różnice między okresem powstania firm informatycznych a podjęciem działalności informatycznej (tab. 1, 2). Spośród 700 
dominujących w 2002 r. firm informatycznych w Polsce, zmiany profilu działalności dokonało 294 firmy, tj. 42,0\% ich ogólnej liczby. Podejmowały one działalność informatyczną po 2, a nawet po ponad 30 latach swojego istnienia. Najliczniejsza grupa firm, która przejęła działalność informatyczną dokonała tego po od 2 do 10 lat swojego istnienia. Łacznie w tej grupie są 223 firmy, tj. 31,9\%. Natomiast tylko stosunkowo nieliczne firmy zmieniały swoją działalność na informatyczną po 16 latach swojej działalności, a reprezentuje je tylko 27 firm, czyli 3,8\%. Świadczy to o tym, iż firmy zmieniające swój profil działalności odznaczały się dużą elastycznością i wraz z pojawieniem się nowego sektora informatycznego dostosowały swoją działalność do nowych warunków i możliwości rozwojowych. Lokalizacja pozostałych 406 firm, tj. 56,0\% dokonywana była pod wpływem nowych czynników związanych z kształtowaniem się społeczeństwa informacyjnego i od początku swojego istnienia związane było z działalnością informatyczną.

Tabela 1. Firmy informatyczne w Polsce w 2003 r. wg roku podjęcia działalności informatycznej

\begin{tabular}{|c|c|c|c|c|}
\hline \multirow{2}{*}{$\begin{array}{l}\text { Rok podjęcia działalno- } \\
\text { ści informatycznej }\end{array}$} & \multirow{2}{*}{ Liczba firm } & \multirow{2}{*}{ Przychody } & \multicolumn{2}{|c|}{ Struktura } \\
\hline & & & liczebności firm & przychodów \\
\hline 1944 & 1 & 8000 & 0,14 & 0,04 \\
\hline 1964 & 1 & 4150 & 0,14 & 0,02 \\
\hline 1977 & 1 & 4701 & 0,14 & 0,02 \\
\hline 1983 & 1 & 17828 & 0,14 & 0,08 \\
\hline 1984 & 1 & 7706 & 0,14 & 0,03 \\
\hline 1985 & 1 & 1427 & 0,14 & 0,01 \\
\hline 1986 & 8 & 113782 & 1,14 & 0,51 \\
\hline 1987 & 19 & 506413 & 2,71 & 2,25 \\
\hline 1988 & 19 & 1292620 & 2,71 & 5,75 \\
\hline 1989 & 17 & 453463 & 2,43 & 2,02 \\
\hline 1990 & 29 & 1191365 & 4,14 & 5,30 \\
\hline 1991 & 49 & 2093780 & 7,00 & 9,32 \\
\hline 1992 & 42 & 1520776 & 6,00 & 6,77 \\
\hline 1993 & 36 & 728034 & 5,14 & 3,24 \\
\hline 1994 & 36 & 1248949 & 5,14 & 5,56 \\
\hline 1995 & 52 & 1724840 & 7,43 & 7,67 \\
\hline 1996 & 37 & 2369213 & 5,29 & 10,54 \\
\hline 1997 & 54 & 2684922 & 7,71 & 11,95 \\
\hline 1998 & 50 & 1630744 & 7,14 & 7,26 \\
\hline 1999 & 58 & 2136951 & 8,29 & 9,51 \\
\hline 2000 & 71 & 1543859 & 10,14 & 6,87 \\
\hline 2001 & 67 & 783268 & 9,57 & 3,48 \\
\hline 2002 & 34 & 248203 & 4,86 & 1,10 \\
\hline 2003 & 6 & 91772 & 0,86 & 0,41 \\
\hline $\mathrm{x}$ & 10 & 70250 & 1,43 & 0,31 \\
\hline Ogółem & 700 & 22477016 & 100,00 & 100,00 \\
\hline
\end{tabular}


Źródło: Obliczenia własne na podstawie - Raport Teleinfo 500. Polski rynek informatyczny 2002, Migut-media, Warszawa, lipiec 2003

Tabela 2. Firmy informatyczne w Polsce w 2003 r. według roku powstania

\begin{tabular}{|c|c|c|c|c|}
\hline \multirow{2}{*}{$\begin{array}{l}\text { Rok podjęcia działalności } \\
\text { informatycznej }\end{array}$} & \multirow{2}{*}{ Liczba firm } & \multirow{2}{*}{ Przychody } & \multicolumn{2}{|c|}{ Struktura } \\
\hline & & & liczebności firm & przychodów \\
\hline 1944 & 1 & 8000 & 0,14 & 0,04 \\
\hline 1951 & 1 & 41480 & 0,14 & 0,18 \\
\hline 1954 & 1 & 2660 & 0,14 & 0,01 \\
\hline 1955 & 1 & 2570 & 0,14 & 0,01 \\
\hline 1963 & 2 & 60514 & 0,29 & 0,27 \\
\hline 1964 & 1 & 4150 & 0,14 & 0,02 \\
\hline 1965 & 6 & 166258 & 0,86 & 0,74 \\
\hline 1966 & 4 & 79402 & 0,57 & 0,35 \\
\hline 1967 & 3 & 37279 & 0,43 & 0,17 \\
\hline 1968 & 1 & 18733 & 0,14 & 0,08 \\
\hline 1971 & 3 & 91312 & 0,43 & 0,41 \\
\hline 1972 & 2 & 163570 & 0,29 & 0,73 \\
\hline 1973 & 1 & 284 & 0,14 & 0,00 \\
\hline 1974 & 1 & 37724 & 0,14 & 0,17 \\
\hline 1975 & 2 & 15752 & 0,29 & 0,07 \\
\hline 1976 & 1 & 11898 & 0,14 & 0,05 \\
\hline 1977 & 1 & 4701 & 0,14 & 0,02 \\
\hline 1978 & 2 & 43676 & 0,29 & 0,19 \\
\hline 1982 & 1 & 4689 & 0,14 & 0,02 \\
\hline 1983 & 6 & 222813 & 0,86 & 0,99 \\
\hline 1984 & 3 & 162827 & 0,43 & 0,72 \\
\hline 1985 & 6 & 16138 & 0,86 & 0,07 \\
\hline 1986 & 16 & 566452 & 2,29 & 2,52 \\
\hline 1987 & 32 & 1138858 & 4,57 & 5,07 \\
\hline 1988 & 32 & 1847815 & 4,57 & 8,22 \\
\hline 1989 & 48 & 1604335 & 6,86 & 7,14 \\
\hline 1990 & 62 & 3536241 & 8,86 & 15,73 \\
\hline 1991 & 85 & 3913079 & 12,14 & 17,41 \\
\hline 1992 & 57 & 2358691 & 8,14 & 10,49 \\
\hline 1993 & 45 & 1014121 & 6,43 & 4,51 \\
\hline 1994 & 34 & 673339 & 4,86 & 3,00 \\
\hline 1995 & 31 & 594764 & 4,43 & 2,65 \\
\hline 1996 & 40 & 793739 & 5,71 & 3,53 \\
\hline 1997 & 30 & 1052892 & 4,29 & 4,68 \\
\hline 1998 & 33 & 345739 & 4,71 & 1,54 \\
\hline 1999 & 33 & 1414832 & 4,71 & 6,29 \\
\hline 2000 & 34 & 145674 & 4,86 & 0,65 \\
\hline 2001 & 17 & 170141 & 2,43 & 0,76 \\
\hline 2002 & 11 & 39624 & 1,57 & 0,18 \\
\hline $\mathrm{x}$ & 10 & 70250 & 1,43 & 0,31 \\
\hline Ogółem & 700 & 22477016 & 100,00 & 100,00 \\
\hline
\end{tabular}


Źródło: Obliczenia własne na podstawie - Raport Teleinfo 500. Polski rynek informatyczny 2002, Migut-media, Warszawa, lipiec 2003.

W latach 1998-2002 następował stopniowy wzrost liczebności obecnie funkcjonujących firm informatycznych, których do $1998 \mathrm{r}$. powstało 416, tj. 59,4\%, a w następnych latach liczba ich wzrosła do 700 (2002). W przestrzeni krajowej poszczególne układy regionalne charakteryzowały się bardzo zróżnicowanymi warunkami dla ich lokalizacji i rozwoju (tab. 3). Wskazuje na to zróżnicowana dynamika przychodów firm oraz ich nierównomierne rozmieszczenia w przestrzeni krajowej (tab. 3).

Przy ogólnej dynamice wzrostu przychodów - 222,8\%, dynamika poszczególnych województw wahała się od 362,0\% (lubelskie) do 105,7\% (opolskie). Ponadtrzykrotnym wzrostem przychodu charakteryzowały się firmy informatyczne województwa lubelskiego i podlaskiego, ale ich udział w ogólnych przychodach był stosunkowo niewielki i zwiększył się z $0,9 \%$ do $1,3 \%$. Od $200 \%$ do $300 \%$ zwiększyły swoje przychody województwa: pomorskie, łódzkie, mazowieckie, kujawsko-pomorskie, śląskie i wielkopolskie, których udział wzrósł z 17,7\% do 19,2\%. Najniższą dynamiką od $105 \%$ do $160 \%$ odznaczały się cztery województwa (małopolskie, podkarpackie, świętokrzyskie, opolskie), których udział w ogólnych przychodach firm informatycznych zmalał z 13,6\% do 9,2\%.

Najkorzystniejsze warunki dla ich rozwoju stwarzało województwo mazowieckie, na terenie którego liczba firm informatycznych zwiększyła się z 181 do 287, ale ich udział w ogólnej liczebności firm zmniejszył się z 43,5\% do 41,0\%. Natomiast pod względem udziału w ogólnych przychodach, udział firm województwa mazowieckiego charakteryzuje się systematycznym wzrostem, z 52,8\% do 57,4\%, podczas gdy obejmuje ono tylko $11,4 \%$ obszaru kraju skupiającego 13,1\% ludności. Zmniejszenie się liczebności firm informatycznych o 2,5 punktów procentowych (pp) oraz zwiększenie się ich udziału o ogólnych dochodach o 10,1pp wskazuje, iż firmy te charakteryzowały się coraz większymi przychodami, co oznacza zarysowujący się proces polaryzacji działalności gospodarczej tego typu firm w przestrzeni krajowej, natomiast stosunkowo mały udział obszaru i ludności wskazuje na znaczną ich koncentrację terytorialna i demograficzną.

Znacznie mniejszą rolę odgrywają pod tym względem pozostałe województwa. Na drugiej pozycji pod względem liczebności firm znalazło się województwo małopolskie, na terenie którego liczba firm informatycznych zwiększyła się z 33 do 69, a ich udział w strukturze krajowej wzrósł z 7,9\% do 9,9\%, natomiast ich udział w ogólnych przychodach zmniejszył się z 11,7\% do 9,3\%. Zwiększenie udziału firm o 2,0pp oraz zmniejszenie ich przychodu o $2,4 \mathrm{pp}$ wskazuje, iż są to firmy o relatywnie mniejszym potencjale.

Trzecią pozycję zajmuje województwo śląskie, na terenie którego dynamika firm była nieco niższa. Mimo wzrostu liczebności firm z 43 do 67, ich udział w strukturze krajowej zmniejszył się z 10,3\% do 9,6\%, a udział w ogólnych przychodach utrzymał się na poziomie 8,3\%.

Czwartą pozycję zajmuje województwo dolnośląskie, którego udział w ogólnej liczebności firm zmniejszył się z 8,2\% do 8,7\%, a w ogólnych przychodach zmalał z 12,3\% do 10,5\%.

Te trzy wspomniane województwa (dolnośląskie, śląskie, małopolskie) odznaczają się mniejszą koncentracją przestrzenną firm informatycznych. Łącznie na ich terenie liczba firm zwiększyła się z 110 do 197, ale ich udział w ogólnej liczbie firm informatycznych nieznacznie zwiększył się z 26,4\% do 28,2\%\%, natomiast ich łączne przychody wyraźnie zmniejszyły się z $32,3 \%$ do $26,8 \%$ ogólnych przychodów, podczas gdy województwa te obejmowały 15,2\% obszaru, na którym zamieszkuje 36,3\% ludności. 
Tabela 3. Rozwój firm informatycznych funkcjonujących w 2002 r.

\begin{tabular}{|c|c|c|c|c|c|c|c|c|c|c|c|c|c|c|}
\hline \multirow{2}{*}{ Województwo } & \multicolumn{5}{|c|}{ Liczba firm } & \multicolumn{5}{|c|}{ Dynamika przychodów ze sprzedaży } & \multicolumn{4}{|c|}{ Udział przychodów firm } \\
\hline & 1998 & 1999 & 2000 & 2001 & 2002 & 1998 & 1999 & 2000 & 2001 & 2002 & 1998 & 1999 & 2000 & 2001 \\
\hline Dolnośląskie & 34 & 45 & 50 & 58 & 61 & 100,0 & 144,7 & 169,6 & 185,0 & 190,5 & 12,3 & 12,1 & 11,1 & 10,6 \\
\hline kujawsko-pomorskie & 11 & 13 & 12 & 15 & 18 & 100,0 & 121,1 & 106,9 & 231,1 & 224,6 & 1,1 & 0,9 & 0,6 & 1,1 \\
\hline Lubelskie & 13 & 15 & 17 & 17 & 19 & 100,0 & 166,5 & 280,8 & 292,7 & 362,0 & 0,5 & 0,5 & 0,7 & 0,7 \\
\hline Lubuskie & 5 & 7 & 10 & 12 & 12 & 100,0 & 103,5 & 118,9 & 156,2 & 194,1 & 0,3 & 0,2 & 0,2 & 0,3 \\
\hline Łódzkie & 10 & 17 & 19 & 24 & 24 & 100,0 & 135,7 & 150,3 & 200,8 & 244,4 & 0,9 &, 8 & 0,7 & 0,8 \\
\hline Małopolskie & 33 & 44 & 51 & 62 & 69 & 100,0 & 135,1 & 163,0 & 174,7 & 152,5 & 11,7 & 10,7 & 10,1 & 9,5 \\
\hline Mazowieckie & 181 & 206 & 236 & 274 & 287 & 100,0 & 144,8 & 193,8 & 225,5 & 242,4 & 52,8 & 51,9 & 54,5 & 55,5 \\
\hline Opolskie & 7 & 7 & 7 & 7 & 7 & 100,0 & 113,1 & 111,3 & 106,2 & 105,7 & 0,3 & 0,2 & 0,2 & 0,1 \\
\hline podkarpackie & 8 & 10 & 10 & 14 & 15 & 100,0 & 123,8 & 132,7 & 133,9 & 151,8 & 1,3 & 1,1 & 0,9 & 0,8 \\
\hline podlaskie & 5 & 8 & 10 & 11 & 11 & 100,0 & 155,2 & 218,1 & 272,8 & 333,4 & 0,4 & 0,4 & 0,4 & 0,5 \\
\hline pomorskie & 21 & 26 & 31 & 35 & 37 & 100,0 & 189,1 & 259,9 & 287,5 & 297,9 & 4,5 & 5,8 & 6,2 & 6,0 \\
\hline śląskie & 43 & 56 & 56 & 64 & 67 & 100,0 & 177,3 & 208,0 & 224,5 & 222,3 & 8,3 & 10,0 & 9,2 & 8,7 \\
\hline świętokrzyskie & 6 & 7 & 7 & 7 & 7 & 100,0 & 133,4 & 136,1 & 152,3 & 125,5 & 0,3 & 0,3 & 0,2 & 0,2 \\
\hline warmińsko-mazurskie & 2 & 2 & 3 & 4 & 4 & 100,0 & 148,7 & 175,5 & 213,6 & 176,4 & 0,5 & 0,5 & 0,5 & 0,5 \\
\hline wielkopolskie & 26 & 31 & 38 & 45 & 46 & 100,0 & 146,2 & 178,4 & 221,8 & 216,3 & 2,9 & 2,9 & 2,8 & 3,0 \\
\hline zachodniopomorskie & 11 & 14 & 16 & 16 & 16 & 100,0 & 122,5 & 146,1 & 176,4 & 188,5 & 2,0 & 1,6 & 1,5 & 1,6 \\
\hline Ogółem & 416 & 508 & 573 & 665 & 700 & 100,0 & 147,2 & 187,6 & 214,5 & 222,8 & 100,0 & 100,0 & 100,0 & 100,0 \\
\hline
\end{tabular}

Źródło: Obliczenia własne na podstawie - Raport Teleinfo 500. Polski rynek informatyczny 2002, Migutmedia, Warszawa, lipiec 2003 
Kolejne pozycje zajmują województwa wielkopolskie, pomorskie i łódzkie, na terenie których funkcjonuje łącznie $15,3 \%$ firm, które dostarczają 9,8\% przychodów, a zajmują $21,2 \%$ obszaru z 21,2\% ludności.

Najmniej atrakcyjne dla lokalizacji firm informatycznych były tereny województw mazursko-warmińskiego, świętokrzyskiego i opolskiego. Na ich obszarze działało tylko 18 firm, które stanowiły 2,6\% ogólnej ich liczby i generowały $0,7 \%$ całości przychodów, podczas gdy obejmowały $14,4 \%$ obszaru, który zamieszkiwało 10,0\% ludności.

Relacja liczebności firm, ich przychodów oraz udziału powierzchni i ludności poszczególnych województw wskazuje na znaczna koncentrację przestrzenną firm informatycznych, co podkreśla zróżnicowane warunki rozwoju firm informatycznych na ich terenie. W analizowanym okresie zaznacza się jednak niewielka tendencja do nieznacznego wyrównywania dysproporcji przestrzennych w tym zakresie, na co wskazują zmniejszające się wskaźniki koncentracji terytorialnej przychodów1 firm z 0,434 w 1998 r. do 0,425 w 2002 r. oraz wskaźników koncentracji demograficznej przychodów2 firm odpowiednio z 0,585 do 0,577 .

Zarysowane tendencje zmian koncentracji działalności firm informatycznych wpłynęły więc w niewielkim stopniu na wyrównywaniu dysproporcji w tym zakresie, na co wskazuje stosunkowo mała wartość współczynnika redystrybucji udziału przychodów3 firm poszczególnych województw, który wynosi 0,067 . Na jego wartość w podstawowym stopniu wpłynęły z jednej strony zwiększające się udziały w ogólnych przychodach województwa mazowieckiego o 4,6 pp oraz województwa pomorskiego o 1,5 pp, a z drugiej województwa, które charakteryzowały się najpoważniejszym zmniejszeniem udziału w przychodach firm informatycznych (małopolskiego o 3,7 pp i dolnośląskiego o 1,7 pp).

${ }^{1}$ Wskaźnik koncentracji terytorialnej przychodów firm informatycznych $\left(\mathrm{k}_{\mathrm{o}}\right)$ obliczono na podstawie wzoru:

$$
k_{o}=\frac{\sum_{i=1}^{n}\left|d_{i}-o_{i}\right|}{200}
$$

gdzie:

d - udział przychodów firm informatycznych i-tego województwa w ogólnych przychodach firm krajowych, o - udział obszaru i-tego województwa w ogólnej powierzchni kraju,

${ }^{2}$ Wskaźnik koncentracji demograficznej przychodów firm informatycznych obliczono na podstawie wzoru:

$$
k_{l}=\frac{\sum_{i=1}^{n}\left|d_{i}-l_{i}\right|}{200}
$$

gdzie:

d-udział przychodów firm informatycznych i-tego województwa w ogólnych przychodach firm krajowych,

1 - udział ludności i-tego województwa w ogólnej liczbie ludności kraju,

${ }^{3}$ Wskaźnik redystrybucji przychodów firm informatycznych (z) w latach 1998-2002 obliczono na podstawie wzoru:

$$
z=\frac{\sum_{i=1}^{n}\left|d_{i}^{t 1}-d^{t 2}{ }_{i}\right|}{200}
$$

gdzie:

d-udział przychodów firm informatycznych i-tego województwa w t $t_{1}$ (1998) i t $t_{2}$ (2002) w ogólnych przychodach firm krajowych. 
Potencjał firm informatycznych w przestrzeni krajowej wykazuje najsilniejsze powiązania z poziomem rozwoju gospodarczego wyrażony wartością PKB. Wyrazem tego jest wysoki współczynnik korelacji wartości PKB z wielkością przychodów wynoszący 0,991 oraz liczbą firm - 0,912. Natomiast potencjał ten w nieco mniejszym stopniu związany jest z liczbą pracujących w gospodarce narodowej, dla której wartość współczynnika korelacji w stosunku do przychodu wynosi 0,786 , a liczby firm - 0,850. Natomiast najsłabszy związek zaznacza się między liczbą ludności a liczbą firm - 0,776 i wartością przychodów 0,705 . Wskazuje to na silne powiązania rozwoju działalności firm informatycznych z poziomem rozwoju gospodarczego, mierzonego wielkością PKB, a w mniejszym stopniu z rozmiarami rynków pracy i potencjałem demograficznym.

Wskaźniki nasilenia liczby firm oraz wartości przychodów na powierzchnię i liczbę mieszkańców obrazują bardzo zróżnicowaną strukturę przestrzenną kraju w zakresie poziomu informatyzacji województw (tab. 4). Podkreślają to wartości przychodów firm informatycznych na jednego mieszkańca, które wahają się od 2,5 tys. zł do 0,03 tys. zł, przy wartości współczynnika zmienności odchylenia standardowego - 165,9\%. Dominujące znaczenie pod tym względem ma województwo mazowieckie odznaczające się najwyższym wskaźnikiem przychodu firm informatycznych na mieszkańca - 2,5 tys. zł. Drugą grupę o wysokich wskaźnikach tworzą województwa dolnośląskie $(0,8$ tys. zł), pomorskie (0,6 tys. zł) i małopolskie (0,6 tys. zł). Trzecia grupa obejmuje pięć województw (śląskie, zachodniopomorskie, wielkopolskie, kujawsko-pomorskie i podlaskie), które charakteryzują się wartościami wskaźników od 0,1 tys. do 0,4 tys. zł. Znacznie niższymi wartościami wskaźników (od 0,05 do 0,1) odznacza się kolejna grupa województw (podkarpackie, łódzkie, lubelskie, lubuskie, warmińsko-mazurskie). Natomiast najniższymi wartościami odznaczają się dwa pozostałe województwa (świętokrzyskie, opolskie).

W układzie przestrzennym wyraźnie zaznacza się położone w centralnej części województwo mazowieckie, zwarta grupa województw północno-zachodnich (zachodniopomorskie, wielkopolskie, kujawsko-pomorskie) o średnich wartościach wskaźników oraz strefa województw wschodnich o najniższych wskaźnikach wskaźników (poniżej 0,1 tys.) ciągnąca się od województwa warmińsko-mazurskiego po województwo podkarpackie.

Podobny układ przestrzenny województw przedstawia nam wartość wskaźnika liczby firm na 100 tys. mieszkańców. Również zdecydowanie wyróżnia się tu województwo mazowieckie o najwyższym wskaźniku (5,6 firmy na 100 tys. mieszkańców), dwa południowe województwa (małopolskie, dolnośląskie) oraz zwarty obszar województw zachodnich o wartości wskaźników (od 1 do 2) oraz dwa pasmowe układy województw o najniższych wskaźnikach (poniżej 1) ciągnące się od województwa kujawsko-pomorskiego przez województwo łódzkie do opolskiego oraz województwa wschodniej Polski od województwa warmińsko-mazurskiego po województwo podkarpackie.

$\mathrm{Na}$ różnice wartości analizowanych wskaźników wpływa potencjał firm informatycznych poszczególnych województw, którego wyrazem jest wskaźnik wartości przychodów na 1 firmę, wahający się od 45,0 mln zł w województwie mazowieckim do 4,5 mln w województwie opolskim. Wysokimi wskaźnikami (od $35 \mathrm{mln}$ do $40 \mathrm{mln}$ zl) cechują się województwa dolnośląskie i pomorskie, natomiast najniższymi (poniżej $10 \mathrm{mln}$ zl) województwa: opolskie, świętokrzyskie, łódzkie i lubelskie. 
Tabela 4. Oddziaływanie firm informatycznych na przestrzeń krajową w 2002 r.

\begin{tabular}{|c|c|c|c|c|c|c|c|c|c|c|}
\hline \multirow{3}{*}{$\begin{array}{l}\text { Wojewódz- } \\
\text { two }\end{array}$} & \multicolumn{5}{|c|}{ Wskaźniki natężenia } & \multicolumn{5}{|c|}{ Odchylenie od średniej krajowej } \\
\hline & \multicolumn{2}{|c|}{ Liczba firm na: } & \multicolumn{2}{|c|}{$\begin{array}{l}\text { Przychody } \\
\text { firm na: }\end{array}$} & \multirow{2}{*}{$\begin{array}{c}\text { Przy- } \\
\text { chód } \\
\text { na } \\
\text { firmę } \\
\text { tys. } \\
\text { w zł }\end{array}$} & \multicolumn{2}{|c|}{ Liczba firm na: } & \multicolumn{2}{|c|}{$\begin{array}{c}\text { Przychody firm } \\
\text { na: }\end{array}$} & \multirow{2}{*}{$\begin{array}{c}\text { Przy- } \\
\text { chód } \\
\text { na } \\
\text { firmę } \\
\text { tys. } \\
\text { w zł }\end{array}$} \\
\hline & $\begin{array}{l}100 \\
\mathrm{~km}^{2}\end{array}$ & $\begin{array}{l}100000 \\
\text { miesz- } \\
\text { kańców }\end{array}$ & $\mathrm{km}^{2}$ & $\begin{array}{l}\text { miesz- } \\
\text { kańca }\end{array}$ & & $\begin{array}{l}100 \\
\mathrm{~km}^{2}\end{array}$ & $\begin{array}{l}100000 \\
\text { miesz- } \\
\text { kańców }\end{array}$ & $\mathrm{km}^{2}$ & $\begin{array}{l}\text { miesz- } \\
\text { kańca }\end{array}$ & \\
\hline dolnośląskie & 3,1 & 2,1 & 118,4 & 812,9 & 38709 & 136,6 & 114,7 & 164,7 & 138,2 & 120,6 \\
\hline & 1,0 & 0,9 & 13,3 & 115,4 & 13262 & 44,7 & 47,5 & 18,5 & 19,6 & 41,3 \\
\hline Lubelskie & 0,8 & 0,9 & 6,9 & 79,4 & 9180 & 33,8 & 47,2 & 9,7 & 13,5 & 28,6 \\
\hline Lubuskie & 0,9 & 1,2 & 4,9 & 67,5 & 5675 & 38,3 & 65,0 & 6,8 & 11,5 & 17,7 \\
\hline łódzkie & 1,3 & & & & 8798 & & & 16,1 & 13,8 & 27,4 \\
\hline małopolskie & 4,6 & 2,1 & 119,0 & 555,3 & 26052 & 204,0 & 116,4 & 165,5 & 94,4 & 81,1 \\
\hline mazowieckie & 8,1 & 5,6 & 362,8 & 2516,9 & 44976 & 360,3 & 305,5 & 504,7 & 428,0 & 140,1 \\
\hline opolskie & 0,7 & & & & 4491 & 33,2 & 36,0 & 4,6 & 5,0 & 14,0 \\
\hline podkarpackie & 0,8 & 0,7 & 11,3 & 96,3 & 13515 & 37,4 & 38,9 & 15,7 & 16,4 & 42,1 \\
\hline podlaskie & 0,5 & 0,9 & 6,0 & 100,4 & 11023 & 24,3 & 49,7 & 8,4 & 17,1 & 34,3 \\
\hline pomorskie & 2,0 & 1,7 & & 618,5 & 36501 & 90,3 & 92,5 & 102,7 & 105,2 & 113,7 \\
\hline śląskie & 5,4 & 1,4 & 151,2 & 394,1 & 27831 & 242,7 & 77,3 & 210,4 & 67,0 & 86,7 \\
\hline świętokrzyskie & 0,6 & 0,5 & 3,2 & 29,1 & 5379 & 26,7 & 29,5 & 4,5 & 4,9 & 16,8 \\
\hline $\begin{array}{l}\text { warmińsko- } \\
\text { mazurskie }\end{array}$ & 0,2 & 0,3 & 3,9 & 66,7 & 23814 & 7,4 & 15,3 & 5,5 & 11,3 & 74,2 \\
\hline wielkopolskie & 1,5 & 1,4 & 21,5 & 191,3 & 13951 & 68,9 & 74,9 & 29,9 & 32,5 & 43,4 \\
\hline $\begin{array}{l}\text { zachodniopo- } \\
\text { morskie }\end{array}$ & 0,7 & 0,9 & 16,3 & 219,3 & 23271 & 31,2 & 51,5 & 22,6 & 37,3 & 72,5 \\
\hline Ogółem & 2,2 & 1,8 & 71,9 & 588,1 & 32110 & 100,0 & 100,0 & 100,0 & 100,0 & 100,0 \\
\hline
\end{tabular}

Źródło: Obliczenia własne na podstawie - Raport Teleinfo 500. Polski rynek informatyczny 2002, Migut-media, Warszawa, lipiec 2003.

Przedstawiona analiza wskazuje, iż przestrzeń krajowa stwarza bardzo zróżnicowane warunki dla powstawania nowoczesnych firm związanych z informacyjną fazą rozwoju społecznego. Generalnie nasilenie występowania tego typu firm nawiązuje do poziomu rozwoju gospodarczego, o czym świadczy wysoki wskaźnik korelacji między firmami a PKB. Przestrzenny obraz informatyzacji kraju podkreśla znaczenie województwa mazowieckiego jako wiodącego ogniwa gospodarczego kraju, a także województw małopolskiego i dolnośląskiego. Poza nimi wyróżnia się generalnie grupa województw zachodnich o wyższych wskaźnikach nasilenia procesów informatyzacji oraz grupa województw wschodnich o najniższym stopniu nasycenia działalnością firm informatycznych. Podstawowy wpływ na taki układ mają regionalne rynki stwarzające zapotrzebowanie na usługi informatyczne nawiązujące do poziomu rozwoju gospodarczego oraz poziom kwalifikacji informatycznych. Wydaje się, iż na obszarach Polski wschodniej konieczne jest upowszechnienie kształcenia informatycznego, co powinno pociagnąć za sobą pojawianie się firm informatycznych podejmujących e-pracę na odległość. Procesy te dają pozytywne re- 
zultaty (m.in. upowszechnia się tego typu praca w Indiach, gdzie prowadzą swoją księgowość liczne firmy amerykańskie). Powinny temu sprzyjać korzystne warunki przyrodnicze, które w Polsce wschodniej są szczególnie atrakcyjne jako miejsca zamieszkania wysoko kwalifikowanej kadry informatycznej.

\section{Literatura}

Gospodarka oparta na wiedzy. Wyzwanie dla Polski XXI wieku, 2001, red. A. Kukliński, Warszawa Wierzbicki A.P., 1995, Perspektywy cywilizacji światowej XXI wieku a przemiany w Polsce, [w:] Świat przyszłości a Polska. Komitet Prognoz „Polska w XXI wieku”, Warszawa

Zioło Z., 2001, Informatyzacja przestrzeni gospodarczej jako wyznacznik konkurencyjności regionu, [w:] Konkurencyjność miast i regionów a przedsiębiorczość i przemiany strukturalne, red. A. Klasik, Prace Naukowe AE w Katowicach, Katowice, s. 37-57 